5. Selivon M.F. Pro deiaki pytannia vzaiemodii sudiv iz mizhnarodnym komertsiinym arbitrazhem [Regarding Several Issues on Interaction of Courts with International Commercial Arbitration]. Pravo Ukrainy. 2014. №12. p.27-36 [in Ukrainian]

6. Humeniuk V.I. Pravovi aspekty diialnosti mizhnarodnoho komertsiinoho arbitrazhu [Legal Aspects of International Commercial Arbitration Activity].Pravo Ukrainy. 2008. №4. p. 139-145 [in Ukrainian]

7. Voloshchuk O.T. Poniattia ta pravova pryroda arbitrazhu. Naukovyi visnyk Chernivetskoho universytetu [Term and Legal Nature of Arbitration]. Pravoznavstvo. Chernivtsi, 2009. №489. p. 51 - 55 [in Ukrainian]

8. Pro mizhnarodnyi komertsiinyi arbitrazh [On International Commercial Arbitration]: Zakon Ukrainy 4002-XII vid 24.02.1994 r. Vidomosti Verkhovnoi Rady Ukrainy (VVR). 1994. № 25. p.198 [in Ukrainian]

9. Chyrych O. Pravo mizhnarodnoho torhovoho arbitrazhu vyrishuvaty pytannia shchodo vlasnoi yurysdyktsii [Authorization of International Commercial Arbitration to Decide whether Its Own Jurisdiction is Available]. Pravo Ukrainy. 2011. №1. p. 97-107 [in Ukrainian]

10. Zakharchenko T.H. Derzhavnyi sud yak harant dotrymannia oboiazkovosti arbitrazhnoi uhody pry podanni do noho pozovu po suti sporu [State Court as Guarantor of Arbitration Agreement Binding where Court Claim is Submitted]. Pravo Ukrainy. 2014. №12. p.65-72 [in Ukrainian]

11. Maidanyk R.A. Maidanik R.A. Arbitrazhnoe soglashenie v mezhdunarodnom kommercheskom arbitrazhe: priroda, lichnyi status, tcessiia [Arbitration Agreement in International Commercial Arbitration: Nature, Status, Assignment]. Almanakh tcivilistiki: sbornik statei. Kyiv: Alerta; TsUL, 2011. p. 361-386. [in Russian]

12. Karabelnikov B.R. Mezhdunarodnyi kommercheskii arbitrazh [International Commercial Arbitration]: ucheb. M., 2012. 51 p. [in Russian]

13. Voloshchuk O.T., Hetmantsev M.O. Arbitrazh AD HOC poniattia ta spetsyfichni rysy [Arbitration Ad Hoc. Meaning and Special Features]. Yurydychna Ukraina. Kyiv, 2019. № 1-2. p. 60-69. [in Ukrainian]

14. Pushkar P.V. Zabezpechennia efektyvnoi diialnosti mizhnarodnykh sudovykh orhaniv ta arbitrazhnykh ustanov: deiaki teoretychni aspekty vidpovidalnosti derzhavy [Provision of Effective Functioning of International Courts and Arbitral Courts: Some Theoretical Issues of State's Responsibility]. Pro ukrainske pravo. Chasopys kafedry teorii ta istorii derzhavy i prava Kyiv. nats. un-tu imeni Tarasa Shevchenka. Za red. prof. I. Bezkluboho. K., 2010. p. 83-86. [in Ukrainian]

\title{
DOI https://doi.org/10.51647/kelm.2020.5.4.31
}

\section{FUNKCJA PLANOWANIA W DZIAŁALNOŚCI NARODOWEJ POLICJI W ZAKRESIE OCHRONY LASÓW}

\author{
Yana Cherniavska \\ studentka Katedry Prawa Administracyjnego i Celnego \\ Uniwersytetu Sprawy Celnej i Finansów (Dniepr, Ukraina) \\ ORCID ID: 0000-0002-5418-172X \\ Cherniavska@gmail.com
}

\begin{abstract}
Adnotacja. Artykuł pokazuje, że proces planowania działań Narodowej Policji w zakresie ochrony lasów jest traktowany jako etap procesu zarządzania. W celu wywierania wpływu na organizację procesu ochrony lasów rozważana jest funkcja administracji, która jest dość złożonym zestawem działań, operacji i czynności, których przeprowadzenie powinno opierać się na systemie zasad. Pojęcie to rozumie zasady, wzorce, teorie, poglądy doktrynalne naukowców, które określają istotę, treść, kierunki procesu planowania.

Udowodniono, że proces efektywności planowania, na podstawie którego są określane działania policji w zakresie ochrony lasów, wiąże się z takimi zasadami: legalność, aktualność, naukowość, obiektywizm i konkretność.

Zaproponowano klasyfikację planów akceptowanych przez Narodową Policję Ukrainy w zakresie ochrony lasów na trzy grupy: ogólne, specjalne, indywidualne. Pozwala to w pełni objąć kompleks złożonych zagadnień związanych ze specyfiką lasów ukraińskich i określić praktyczne środki ich realizacji.

Ustalono, że ważnym etapem planowania jest podjęcie decyzji o ich realizacji, które stanowi apodyktyczną, organizacyjną decyzję podmiotu administracji publicznej. Taka procedura ma ustaloną formę z obowiązkowymi danymi, podpisami upoważnionych osób i jest przekazywana wykonawcom z wyprzedzeniem. Wykazano, że biorąc pod uwagę specyfikę zadań związanych z ochroną lasu, w treści planów wskazane jest udokumentowanie takich działań, jak upowszechnianie wiedzy prawnej o potrzebie ochrony lasu w instytucjach edukacyjnych, mediach, działalności wydawniczej. Udowodniono, że skutecznym sposobem ochrony tego zasobu jest informowanie społeczeństwa, organizowanie otwartych spotkań z przedstawicielami organizacji społecznych, identyfikowanie problematycznych kwestii leśnictwa i wykorzystywanie sposobów rozwiązywania tych problemów.
\end{abstract}

Słowa kluczowe: Narodowa Policja; Państwowa Straż Leśna; Państwowa Agencja Zasobów Leśnych; proces zarządzania; ochrona lasów; planowanie; prawo w zakresie ochrony lasu. 


\title{
PLANNING FUNCTION IN ACTIVITIES OF THE NATIONAL POLICE OF UKRAINE IN TERMS OF FOREST CONSERVATION
}

\author{
Yana Cherniavska \\ Applicant at the Department of Administrative and Customs Law \\ University of Customs and Finance (Dnipro, Ukraine) \\ ORCID ID: 0000-0002-5418-172X \\ Cherniavska@gmail.com
}

\begin{abstract}
The article shows that the process of activity planning of the National Police of Ukraine in terms of forest conservation is regarded as a stage of managerial process. In order to influence the organization of the forest protection process, the author considers the administration function, which is a rather complex set of actions, operations and activities, which should be based on a system of principles. This term involves rules, patterns, theories, scientific doctrinal opinions identifying the essence, content, scope of the planning process.

The research proves that the process of effective planning, which determines the activities of the police in the area of forest protection, is associated with the following principles: legality, relevance, scientific nature, objectivity and specificity.

The author proposes to classify the forest protection plans approved by the National Police of Ukraine into three groups: general, special, and individual. This allows one to fully cover a range of complex issues related to the specifics of Ukrainian forests and identify practical means of their implementation.

It is established that an important stage of planning is the decision on their implementation which is an authoritative, organizational decision of the subject of public administration. That kind of procedure has the specific form with mandatory particulars, signatures of the authorized persons and is brought to the executors in advance. The research highlights the expediency of consolidating such actions as dissemination of legal knowledge regarding the need for forest protection in educational institutions, mass media, publishing activities in the plans taking into account the specifics of tasks associated with forest conservation. It justifies that an effective means of protection of this resource involves informing the public, holding open meetings with representatives of non-governmental organizations, identifying problems of forest management and using ways to solve these problems.
\end{abstract}

Key words: National Police, State Forest Resources Agency, State Forest Protection Service, management processes, forest protection, planning, forestry law.

\section{ФУНКЦІЯ ПЛАНУВАННЯ В ДІЯЛЬНОСТІ НАЦІОНАЛЬНОЇ ПОЛІЦІЇ У СФЕРІ ОХОРОНИ ЛІСІВ}

\author{
Яна Чернявська \\ здобувач кафедри адміністративного та митного права \\ Університету митної справи та фінансів (Дніпро, Україна) \\ ORCID ID: 0000-0002-5418-172X \\ Cherniavska@gmail.com
} Анотація. У статті показано, що процес планування діяльності Національної поліції в сфері охорони лісів
розглядєтья як стадія управлінського процесу. 3 метою здійснення впливу на організацію процесу охорони лісів
розглянуто функцію адміністрування, яка являє собою достатньо складний комплекс дій, операцій та заходів, про-
ведення яких повинно базуватися на системі принципів. Під цим терміном розуміють правила, закономірності,
теорії, доктринальні погляди науковців, які визначають сутність, зміст, напрямки процесу планування.
Доведено, що процес ефективності планування, на основі яких визначається діяльність поліції у сфері охоро-
ни лісів, пов'язаний з такими принципами: законність, актуальність, науковість, об'єктивність та конкретність.
Запропоновано класифікувати плани, які приймаються Нацполіцією України в сфері охорони лісів, на три
групи: загальні, спеціальні, індивідуальні. Це дозволяє повністю охопити комплекс складних питань,, пов’язаних
зі специфікою українських лісів та визначити практичні засоби їх реалізації.
Встановлено, що важливою стадією планування є прийняття рішення щодо їх реалізації, яка являє владне,
організаційне рішення суб’єкта публічного управління. Така процедура має встановлену форму з обов’язковими
реквізитами, підписами уповноважених осіб та завчасно доведена до виконавців. Показано, що враховуючи спе-
цифіку завдань, пов’язаних з охороною лісу, в змісті планів доцільно зафіксувати такі заходи, як поширення
правових знань стосовно необхідності охорони лісу в освітніх закладах, засобах масової інформації, видавничій
діяльності. Доводиться, що ефективним засобом охорони цього ресурсу єінформування громадськості, проведен-
ня відкритих зустрічей з представниками громадських організацій, визначення проблемних питань лісової справи
та використання шляхів розв'язання даних проблем.

Ключові слова: Національна поліція, Державна лісова охорона, Державне агентство лісових ресурсів, управлінський процес, охорона лісів, планування, лісоохоронне законодавство.

Вступ. Актуальність теми дослідження пов'язана з двома причинами. По-перше, це необхідність удосконалення діяльності поліції в сфері охорони лісів. Причина такого підходу пов'язана 3 критичним станом цього природного ресурсу, який зазнає нищівних вирубок, захоплення лісових земель, незаконну зміну їх 
цільового призначення та інших факторів порушень законодавства. На практиці часто складається ситуація, коли співробітники Державної лісової охорони не можуть без допомоги Національної поліції ефективно протидіяти правопорушенням. По-друге, проблема охорони лісів є складним завданням, яке потребує використання різних норм, засобів та способів. Реалізація комплексу таких заходів отримала в теорії управління назву - планування діяльності. Виходячи з цього, виникла необхідність дослідити питання планування діяльності Національної поліції в сфері охорони лісів, що повинно дозволити узгодити сумісну роботу іiі підрозділів зі структурами Державного агентства лісових ресурсів.

Основна частина. Викладення матеріалів дослідження необхідно розпочати з того, що по-перше, планування є основою здійснення управлінських процесів в конкретній системі. В юридичній науці існує декілька підходів до категорії планування, які можна систематизувати на наступні групи: 1) функція управління; 2) окремий управлінський процес; 3) стадія процесу управління. Як вказує В.М. Плішкін, як функція управління планування дає змогу визначити цілі заходів на подальший період діяльності з урахуванням факторів, які впливають на стан системи (Плішкін, 1999: 95). По-друге, управлінський процес - планування, яке включає в себе розробку систем, направлених на досягнення результату. По-третє, М.М. Новікова пропонує розглядати планування як початковий процесу управління, пов'язаний зі здійсненням управлінського циклу (Новікова, 2016: 22). На підставі викладених та інших підходів, можна сказати, що планування участі підрозділів Національної поліції в сфері охорони лісів є окремою стадією процесу адміністрування, який складається з комплексу послідовних дій, заходів, їх послідовності, виконавців, термінів реалізації, розподілу фінансових, матеріально-технічних та кадрових ресурсів, спрямованих на ефективний захист цього природного ресурсу від протиправних дій, пожеж та нераціонального використання.

Процес планування являє собою досить складний комплекс дій, операцій та заходів, проведення яких повинно базуватися на системі принципів. Під цим терміном розуміють правила, закономірності, теорії, доктринальні погляди науковців, які визначають сутність, зміст, напрямки процесу планування. За допомогою принципів суб'єкти публічного адміністрування створюють засади розробки дієвих, реальних, раціональних, законодавчо-обгрунтованих планів, зрозумілих для виконавців, які завжди можна перевірити та провести їх коригування. 3 точки зору особливостей планування органів МВС України в сфері охорони лісів, виділяють наступні п’ять видів принципів: 1) законність; 2) актуальність; 3) науковість; 4) об’ єктивність; 5) конкретність.

1. Принции законності передбачає, що діяльність Національної поліції та комплекс заходів, який знаходить свій вираз в плані, повинні здійснюватися на підставі Конституції України, постанов Кабінету Міністрів, відомчих нормативно-правових актів, виданих МВС України, Держлісагентством, в яких регламентується діяльність поліції в сфері охорони лісів. Враховуючи необхідність участі в процесі охорони лісів органів місцевого самоврядування, виникає потреба узгодити їх діяльність з органами внутрішніх справ з урахуванням положень Закону України «Про місцеве самоврядування» та іншими підзаконними актами, які регламентують їх діяльність.

2. Принцип актуальності знаходить своє відображення в тому, що розроблені плани повинні бути важливими для охорони лісів, збереження їх стану та забезпечувати притягання порушників до відповідальності. В практичній діяльності лісових господарств постійно виникають питання, які потребують негайного вирішення, що потребує їх включення до змісту планів. Наприклад, в Україні встановлена заборона на суцільну вирубку ялицево-букових лісів в Карпатах, яка постійно порушується в багатьох випадках за участю працівників Держлісагентства. Цілком зрозуміло, що положення стосовно виявлення таких фактів, їх припинення, повинні знайти відображення в планах. До цього необхідно додати питання вдосконалення діяльності поліції в містах таких рубок, зміни організаційних структур, внутрішніх управлінських процесів, які необхідно включити до змісту планів.

3. Принции науковості, пов'язаний з теоретичними розробками вчених-адміністративістів в сфері управління В.М. Плішкіна, О.М. Бандурки, Т.А. Берегоя, Д.В. Приймаченко та ін. Так, серед науковців уже багато років точиться дискусія щодо правової природи актів планування, сутність якої полягає в тому, що одні розглядують їх як нормативно-правові акти, інші в якості правозастосовних актів. Незважаючи на цю дискусію, можна зазначити, що плани містять приписи щодо вчинення однорідних дій, мають конкретний адресат, строки виконання. На думку Д.В. Приймаченко, при підготовці планів необхідно враховувати ту обставину, що такі документи входять в комплекс актів планування, присвячених конкретній проблемі (Приймаченко, 2013: 55). Одночасно з цим розробники таких документів повинні враховувати досягнення лісівничої науки та досвід лісників, накопичений у цій сфері.

До їх числа відноситься використання моніторингу стану лісів, яка здійснює Українська державна база авіаційної охорони лісів, що дозволяє своєчасно виявити факти незаконних рубок, крадіжок лісу та передати таку інформацію до МВС України. Застосування даного принципу передбачає використання наукових методів пізнання та методів обробки інформації, отриманої з карт і переведення їх до цифрового масиву.

4. Принции об'єктивності полягає у тому, що у процесі планування повинні використовуватися фактичні дані про стан лісів, заходи, які проводяться службами Держлісгоспу. До них належать дані про кількість правопорушень систематичного спостереження, санітарного огляду лісів, рівень пожежної небезпеки, частота відвідування лісів. Важливим джерелом інформації є дані Державної лісової охорони про заходи, які проводяться в лісах її співробітниками, іншими користувачами лісу. Використання даного принципу дозволяє уникнути помилок, що підвищує ефективність запланованих заходів та дотримуватися строків виконання. 
5. Принцип конкретності знаходить свою реалізацію у тому, що комплекс заходів, їх зміст, очікуваний результат в сфері охорони лісів повинен бути чітко вказаним без можливості різного трактування.

Методика розробки планів по організації охорони лісів базується на загальній методиці вироблення і прийняття рішень. Відповідно до неї доцільно планувати тільки такі лісоохоронні заходи, які реально можуть бути проведені силами підрозділів поліції.

Дотримання даного принципу потребує забезпечення виконавців матеріально-технічними ресурсами, кадрами, які мають фахові знання та досвід в сфері охорони лісу. Такий підхід вимагає залучення співробітників Державної лісової охорони, на яких покладено обов'язок здійснення державного контролю за додержанням вимог лісового та мисливського законодавства, п. 4 «Положення про державну лісову охорону». У плані обов'язково повинні бути названі виконавці та відповідальні особи, які будуть безпосередньо організовувати виконання конкретних заходів.

Планування дозволяє найбільш ефективно використовувати сили і засоби Національної поліції для досягнення найкращих результатів при можливо менших витратах. Така діяльність забезпечує рівномірний розподіл роботи, ритмічність діяльності підрозділів і співробітників, чітку взаємодія різних служб і підрозділів. На додаток до цього планування підвищує відповідальність виконавців, спрощує контроль, вивчення і узагальнення позитивного досвіду.

У нормативних актах, що видаються МВС України в останні роки, визначається роль планування як найважливішого засобу забезпечення організованості, злагодженості в роботі за рішенням завдань, поставлених перед органами внутрішніх справ в сучасний період. Так, в Інструкції з організації планування в системі Національної поліції України від 24.12.2015 р. регламентується порядок підготовки планів, які включає в себе вимоги до таких документів, організацію планування, організацію виконання планів, коригування планів, контроль за їх виконанням (Про затвердження Інструкції з організації планування в системі Національної поліції України...). В документі звертається увага на необхідність оформлення плану у вигляді таблиці, яка має такі графи: порядковий номер заходу, назва заходу, відомості про виконавців, строк виконання, очікуваний результат, відмітка про виконання, примітка. Згідно даного нормативно-правового акту, плани в системі Національної поліції поділяються на наступні групи: загальні, спеціальні, індивідуальні (рис. 1).

Виходячи з такої систематизації доцільно розглянути зміст кожної з них шляхом трансформації їх змісту до завдань з охорони лісів.

1. Загальні плани являють собою документ, що визначає обсяг роботи підрозділів поліції за участю співробітників Державного агентства лісових ресурсів відповідно до основних напрямів їхньої діяльності. До цієї категорії відносяться перспективні плани, на підставі яких реалізується Стратегія розвитку органів системи Міністерства внутрішніх справ на період до

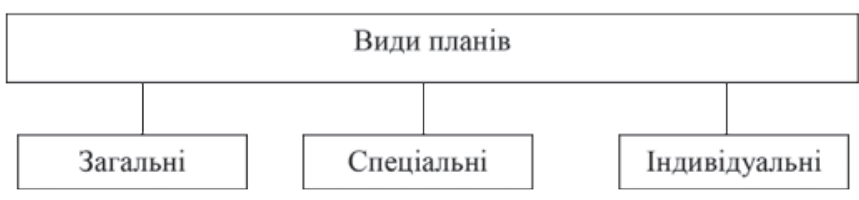

Рис. 1. Види планів в системі Національної поліції України

2020 р., затвердженої наказом МВС України від 15.11. 2017 р. Завданням даного акту є подальша розбудова системи МВС для зміцнення публічної безпеки, правопорядку, забезпечення державної політики у сфері внутрішніх справ. В тексті документу знайшли відображення наступні пріоритети: безпечне навколишнє середовище, протидія злочинності, які тісно пов'язані з питаннями охорони лісу. В деяких випадках використовуються стратегічні плани, які відрізняються від звичайних тим, що в них визначається бажаний план організації діяльності, якого хочуть досягнути в майбутньому. Як вказує М.Б. Свистович, стратегічне планування оцінює перспективи, виявляє можливості, загрози зовнішнього середовища, сильні та слабкі сторони внутрішнього середовища (Свистович, 2015: 39).

Другою категорією загальних планів є поточні плани, завданням яких є визначення практичних засобів для їх реалізації на чітко встановлений плановий період - рік, півріччя, квартал, місяць.

2. Спеціальні плани включають в себе комплекс завдань щодо виконання законодавчих та підзаконних нормативно-правових актів, а також оперативно-профілактичних заходів. Наприклад, «Правила пожежної безпеки в лісах України» затверджені наказом від 27.12.2004 р., №278 Держкомлісгоспу України передбачають проведення організаційних заходів, проведення перевірок за участю співробітників МНС України 3 питань виконання користувачами лісів протипожежних вимог, порядку організації гасіння лісів, наявності технічних засобів.

3. Індивідуальні плани, які являють собою плани роботи співробітників поліції, дільничних інспекторів, в яких необхідно передбачити питання контролю за станом лісів, проведення перевірок «нелегальних пилорам» місць складування лісу.

В своїй діяльності МВС України постійно звертає увагу на необхідність поліпшення якості планування. Однак, проведений автором аналіз показав, що практика планування природоохоронної роботи вимагає значно більшої уваги з боку керівників служб і підрозділів, так і вдосконалення.

На основі аналізу інформації про стан, структуру, динаміку порушень лісоохоронного законодавства, про результативність зусиль всіх служб міліції в боротьбі з ними, і з урахуванням уже визначених цілей і напрямів природоохоронної діяльності складаються плани заходів. Планування надає будь-якої діяльності цілеспрямованість, логічну послідовність і конкретність, а отже, сприяє іï ефективності. Від того, які заплановані заходи 
по боротьбі з порушенням лісоохоронного законодавства на кого покладено їх виконання, і яким чином вони будуть здійснені, залежать результати охорони лісового фонду та лісів, що не входять в лісовий фонд.

При цьому необхідно пов'язати планування лісоохоронної діяльності поліції з загальними планами по боротьбі зі злочинністю. При реалізації здійснення лісоохоронних заходів можливе виявлення і затримання водіїв автотранспортних засобів, що знаходяться під впливом наркотиків в стані сп'яніння; засуджених, які вчинили втечу з місць відбування покарання; дезертирів з лав Збройних Сил України; наркоманів; розшукуваних злочинців тощо. При складанні таких планів необхідно враховувати рекомендації ГУНП МВС України і пропозиції підлеглих підрозділів, соціально-економічну специфіку регіону, кліматичні і природні умови.

Таким чином, план як інструмент організації повинен:

- містити не тільки постановку, а й узгодження завдань і заходів, спрямованих на боротьбу з порушеннями лісоохоронного законодавства та іншими правопорушеннями;

- виділення основного напрямку діяльності;

- передбачати комплексне вирішення поставлених завдань;

- мати систему завдань, вирішення яких веде до виконання головного завдання, узгоджених між собою;

- забезпечувати відповідність завдань функцій, фактичним ресурсам та можливостям виконавців;

- передбачати контроль за здійсненням намічених заходів і коригування плану з урахуванням фактичного розвитку ситуації.

Виходячи з цього, кожен співробітник поліції, який задіяний у виконанні лісоохоронних заходів зобов'язаний скласти індивідуальний план і погодити його з загальним планом. Такі плани найчастіше складаються співробітниками підрозділів поліції, дільничними інспекторами поліції, за участю працівників Державної лісової охорони, які обов’язково готуються при боротьбі з лісовими пожежами та заходами з охорони лісів.

Складання та затвердження плану є лише передумовою вирішення поставленого завдання. Для його реалізації необхідно розробити та прийняття управлінські рішення, які з є стадіями будь-якого управлінського циклу, в тому числі і в організації охорони лісового фонду та лісів, що не входять в лісовий фонд. При цьому необхідно і своєчасно інформувати виконавців про прийняте рішення, що дозволить їм зосередити необхідні технічні, людські та фінансові ресурси. Як вказує К.Л. Бугайчик, планування знаходить свою реалізації на оперативних нарадах, у планах індивідуально-виховної роботи, психопрофілактичної роботи, у роботі колегій ГУНП МВС (Бугайчук, 2019: 88).

Доведення рішення до безпосередніх виконавців може здійснюватися різними шляхами: в усній формі, на нараді, інструктажі, службових заняттях, напрямком письмових вказівок. Це залежить від характеру прийнятого рішення, від числа виконавців і інших обставин у вигляді часового фактору, організаційно-технічних можливостей суб'єкта управління. Причому, чим вище рівень суб'єкта, що прийняв рішення і більше число виконавців, тим, складніше здійснити доведення рішення до них, тим більше уваги вимагає організація цієї роботи.

Характер завдань, що стоять перед поліцією в сфері охорони лісів, вимагає використання всіх перерахованих вище шляхів для доведення рішень до виконавців. Однак, як показує практика, найбільш часто тут використовуються інструктаж, а так само передача рішення по засобам зв'язку, що особливо специфічно для умов здійснення функцій з охорони лісів.

Для кваліфікованого проведення інструктажу необхідно добре знати функціональні обов'язки кожного бере участь в лісоохоронних заходах співробітника, обстановку в якій йому доведеться діяти, умови місцевості, дислокацію органів Держлісагентства. Тому інструктувати виконавців повинен їх керівник, як особа більше інших обізнана про перерахованих обставин, бо відповідальний за організацію природоохоронних заходів.

Треба враховувати і той факт, що у виконанні рішення зазвичай бере значну кількість співробітників, комплекс охорони, працівників поліції, кожен з яких виконує доручене йому конкретне завдання. Для реалізації рішення в цілому необхідно організувати взаємодію між його виконавцями, координувати їх діяльність. Такі заходи передбачають: забезпечення аналітичного підходу до планування, розстановці і використанню сил; поєднання контролю з наданням практичної допомоги; вдосконалення форм зв’ язку з населенням; зміцнення контактів у вирішенні питань з відповідними органами; забезпечення участі служб охорони громадського порядку в роботі по виконанню законодавства про охорону навколишнього середовища.

Практика свідчить, що відсутність узгодженості, низький рівень планування подібної роботи, нераціональна розстановка сил і засобів негативно позначається на рішення органами внутрішніх справ завдань з охорони природних ресурсів країни.

Висновки. За результатами проведеного дослідження можна зробити наступні висновки:

1. Процес планування діяльності Національної поліції в сфері охорони лісів необхідно розглядати як стадію управлінського процесу та функцію адміністрування з метою здійснення впливу на організацію процесу охорони лісів.

2. В змісті планів необхідно передбачити систему заходів, спрямованих на охорону лісу з урахуванням різнорідних факторів, пов'язаних з особливостями цього природного ресурсу, таких як система доріг, яка використовується для вивозу лісу, розташування лісів, наявність населених пунктів, дислокацію органів внутрішніх справ, служб Держлісагенства та лісової охорони.

3. Процес ефективності планування пов'язаний з принципами, до числа яких відносять: законність, актуальність, науковість, об’єктивність та конкретність, на основі яких визначається діяльність поліції у сфері охорони лісів. 
4. Плани, що приймаються Нацполіцією України в сфері охорони лісів доцільно класифікувати та три групи: загальні, спеціальні, індивідуальні, що дозволяє повністю охопити комплекс складних питань, пов’язаних зі специфікою українських лісів та визначити практичні засоби їх реалізації.

5. Важливою стадією планування є ухвалення рішення щодо їх реалізації яка являє владне, організаційне рішення суб'єкта публічного управління. Така процедура має встановлену форму з обов'язковими реквізитами, підписами уповноважених осіб та бути завчасно доведеним до виконавців. Враховуючи специфіку завдань, пов'язаних з охороною лісу, в змісті планів доцільно зафіксувати такі заходи, як поширення правових знань стосовно необхідності охорони лісу в освітніх закладах, засобах масової інформації, видавничій діяльності. На додаток до цього ефективним засобом охорони цього ресурсу є інформування громадськості, проведення відкритих зустрічей з представниками громадських організацій, визначення проблемних питань лісової справи та шляхи розв’язання різних проблем.

\section{Список використаних джерел:}

1. Плішкін В.М. Теорія управління органами внутрішніх справ: підручник. Київ: НАВСУ, 1999. 702 с.

2. Новікова М.М. Конспект лекцій з дисципліни «Менеджмент і адміністрування (адміністративний менеджмент)». Харків: ХНУМГ ім. О. М. Бекетова, 2016. 98 с.

3. Приймаченко Д.В. Правова природа актів планування: сучасний аналіз Публічне право. 2013. № 1. С. 52-58.

4. Про затвердження Інструкції з організації планування в системі Національної поліції України: наказ Національної поліції України від 24.12.2015 р. № 202.

5. Свистович М.Б. Сутність та основні поняття стратегічного планування. Державне управління: теорія та практика. 2013. № 2. С. 37-43.

6. Бугайчук К.Л. Планування у процесі публічного адміністрування в органах Національної поліції. Підприємництво, господарство і право. 2019. № 2. С. 84-89.

\section{References:}

1. Plishkin, V.M. (1999). Teoriia upravlinnia orhanamy vnutrishnikh sprav [Theory of management of law-enforcement bodies]. Kyiv: NAVSU [in Ukrainian].

2. Novikova, M.M.(2016). Konspekt lektsii z dystsypliny «Menedzhment i administruvannia (administratyvnyi menedzhment)» [Synopsis of lectures on the subject «Management and Administration (Administrative Management)»]. Kharkiv: KhNUMH im. O. M. Beketova [in Ukainian].

3. Pryimachenko, D.V. (2013). Pravova pryroda aktiv planuvannia: suchasnyi analiz [Legal nature of planning acts: modern analysis]. Publichne pravo - Public Law Magazine, 1 [in Ukrainian].

4. Pro zatverdzhennia Instruktsii $\mathrm{z}$ orhanizatsii planuvannia v systemi Natsionalnoi politsii Ukrainy: nakaz Natsionalnoi politsii Ukrainy vid 24.12.2015 r. № 202 [On approval of the Instruction on the organization of planning in the system of the National Police of Ukraine: order of the National Police of Ukraine dated 24.12.2015 № 202]. (2015, December 24) [in Ukrainian].

5. Svystovych, M.B. (2013). Sutnist ta osnovni poniattia stratehichnoho planuvannia [The essence and basic concepts of strategic planning]. Derzhavne upravlinnia: teoriia ta praktyka - Public Administration: Theory and Practice, 2, 37-43 [in Ukrainian].

6. Buhaichuk, K.L. (2019). Planuvannia u protsesi publichnoho administruvannia v orhanakh Natsionalnoi politsii [Planning in the process of public administration in the National Police]. Pidpryiemnytstvo, hospodarstvo i pravo - Entrepreneurship, Economy and Law, 2, 84-89 [in Ukrainian]. 